\title{
Adhering to adhesion: assessing integrin conformation to monitor T cells
}

\author{
Cécile Gouttefangeas $^{1,2}$ ([) Juliane Schuhmacher ${ }^{1,2} \cdot$ Stoyan Dimitrov $^{3,4,5}$
}

Received: 3 April 2019 / Accepted: 2 July 2019 / Published online: 15 July 2019

๑) Springer-Verlag GmbH Germany, part of Springer Nature 2019

\begin{abstract}
Monitoring T cells is of major importance for the development of immunotherapies. Recent sophisticated assays can address particular aspects of the anti-tumor T-cell repertoire or support very large-scale immune screening for biomarker discovery. Robust methods for the routine assessment of the quantity and quality of antigen-specific $\mathrm{T}$ cells remain, however, essential. This review discusses selected methods that are commonly used for T-cell monitoring and summarizes the advantages and limitations of these assays. We also present a new functional assay, which specifically detects activated $\beta_{2}$ integrins within a very short time following $\mathrm{CD} 8^{+} \mathrm{T}$-cell stimulation. Because of its unique and favorable characteristics, this assay could be useful for implementation into our T-cell monitoring toolbox.
\end{abstract}

Keywords T cell · Adhesion · Function · Immunomonitoring · Immunotherapy · PIVAC 2018

Abbreviations
$\begin{array}{ll}\text { EBV } & \text { Epstein-Barr virus } \\ \text { FCM } & \text { Flow cytometry } \\ \text { Flu } & \text { Influenza virus }\end{array}$

This paper is a Focussed Research Review based on a presentation given at the Eighteenth International Conference on Progress in Vaccination against Cancer (PIVAC 18), held in Oslo, Norway, 3rd-5th October, 2018. It is part of a Cancer Immunology, Immunotherapy series of PIVAC 18 papers.

Cécile Gouttefangeas

cecile.gouttefangeas@uni-tuebingen.de

Stoyan Dimitrov

stoyan.dimitrov@uni-tuebingen.de

1 Department of Immunology, Interfaculty Institute for Cell Biology, Eberhard Karls University, Auf der Morgenstelle 15, 72076 Tübingen, Germany

2 German Cancer Consortium (DKTK), German Cancer Research Center (DKFZ), Partner Site Tübingen, Tübingen, Germany

3 Institute of Medical Psychology and Behavioral Neurobiology, Eberhard Karls University, Otfried-Müller Straße 25, 72076 Tübingen, Germany

4 German Center for Diabetes Research, 72076 Tübingen, Germany

5 Institute for Diabetes Research and Metabolic Diseases, Helmholtz Center Munich at the University of Tübingen (IDM), Otfried-Müller Straße 10, 72076 Tübingen, Germany
mICAM-1 Multimers of Intercellular adhesion molecule 1

LFA-1 Lymphocyte function-associated antigen 1

pMHC Peptide major histocompatibility complex

YFV Yellow fever virus

\section{The importance of T-cell monitoring}

$\mathrm{T}$ cells are key actors in many cancer immunotherapy approaches. With the increasing development of checkpoint blockade antibodies, adoptive transfer therapies, and newgeneration cancer vaccines, the assessment of immune cell subsets has become indispensable. Monitoring of patient (T) cells delivers information on the mechanisms of action, persistence of transferred effector cells, and possibly on therapy resistance. In the context of vaccine development, it establishes immunogenicity of antigens and efficacy of adjuvants, and guides the choice of immune modulators and therapy combinations. It has also the potential to reveal early biomarkers of clinical efficacy [1].

Recent developments in genomics and in profiling of (single cell) TCR clonotypes [2, 3] now allow browsing the full T-cell repertoire from very few starting material. Coupled to methods for enriching selected antigen-specificities, they could soon deliver precious information on anti-tumor T-cell response dynamics in cancer patients [4]. These sophisticated, extremely high-throughput approaches are until now 
reserved to a few expert teams and associated with specific challenges [5]. Hence, straightforward T-cell immunomonitoring methods that can be relatively easily implemented in daily laboratory practice remain crucial tools for clinical development.

In the following paragraphs, we discuss those aspects of the most popular assays that we believe should be considered as basics in the context of clinical T-cell immunomonitoring. We also describe a new method that we have recently developed, and which relies on a so far unexploited early event of T-cell activation, i.e., the conformational and valency change of membrane-bound $\beta_{2}$ integrins.

\section{Common methods for assessing antigen-specific $T$ cells and their function}

Antigen-specific T cells can be identified by phenotypic and/ or functional hallmarks. In most settings, functional assessment requires an in vitro cell (e.g., whole blood or peripheral blood mononuclear cells, i.e., PBMCs) re-stimulation phase in the presence of the relevant antigen(s) to be tested. Read-out can be then performed by measuring the upregulation of activation factors, the proliferation, the production of cytokines, and cytotoxic attributes such as degranulation or perforin/granzyme amounts.

For the monitoring of clinical studies, immune tests should be robust, able to detect low-frequency $\mathrm{T}$ cells from a limited amount of material, and amenable to a high number of samples. In addition, methods and instrumentation need to be stable over longer periods of time, possibly years, to allow a comparison of results obtained at various time points during therapy/follow-up and from different patients enrolled in the trial. A number of methods are available for measuring T-cell antigen specificity and function. Since there is no gold standard, they are employed according to the specific need and local know-how of the different immunomonitoring laboratories. The most widely used assays are the Enzyme-Linked Immunospot (ELISpot) and the flow cytometry-based methods that include peptide-MHC (pMHC) multimer staining and intra-cellular cytokine staining (ICS). These tests deliver complementary information on the quantity and quality of the T cells and should be carefully chosen during the preparation phase of a study. The main characteristics, advantages, and limitations of these assays are discussed below and summarized in Table 1.

\section{The ELISpot: simple but refined}

The ELISpot method was first described more than 30 years ago [6]. It is a relatively high-throughput method that can be used for measuring a variety of secreted factors, provided that two monoclonal antibodies recognizing different epitopes of the targeted molecule (soluble analyte) are available. Interferon- $\gamma$ (IFN- $\gamma$ ) is mostly used for assessing antigen-specific $\mathrm{T}$ cells, as this cytokine is produced in substantial quantity by both activated $\mathrm{CD} 4^{+}$ and $\mathrm{CD} 8^{+} \mathrm{T}$ cells.

Briefly, suitable membrane-bottomed 96-well plates are coated with a monoclonal antibody $(\mathrm{mAb})$ recognizing the analyte of interest, e.g., IFN- $\gamma$. Cells are then added to the well and stimulated with the antigen [in general, short epitopes or long ( $>20$ amino acids) overlapping peptides are used]. After cell removal, a second biotinylated anti-IFN- $\gamma$ $\mathrm{mAb}$ is added, followed by a streptavidin-coupled enzyme (e.g., alkaline phosphatase or horseradish peroxidase). Each activated and IFN- $\gamma$-secreting cell will give a colored spot after final incubation with a suitable precipitating substrate. The exact number of spots can be counted with an ELISpot reader and the frequency of antigen-specific cells calculated. Size of the spots, which gives information on the quantity and kinetics of cytokine production, is more rarely analyzed. The ELISpot assay is of high sensitivity, specificity, and accuracy due to the two antibodies recognizing different epitopes of the same analyte and to the signal amplification provided by the biotin-streptavidin interaction [7]. The technique can reach a detection limit of approximately 4-7 spots per 100,000 PBMCs $(0.004-0.007 \%)$ in experienced laboratories $[8,9]$, whereas the upper limit of quantification depends on the number of spots that can be discriminated by the ELISpot reader (typically between 1000 and 1500 spots/ well). In most cases, cells are stimulated for $24-40 \mathrm{~h}$, allowing for detection of late cytokines [10]. The duration of the stimulation is actually limited by the number of cells in the wells and the medium consumption. Although measurement of 2-3 parameters is possible, the assay is still mainly used as a mono-parametric test. Overall, ELISpot is a robust and sensitive method, but does not allow the identification of cytokine-secreting cell populations unless these are purified beforehand; this is rarely done with limited patient material.

The ELISpot method has been widely discussed and improved over the years, and very helpful guidelines and protocols are available $[7,9,11]$. As it is the case for any other assay including living cells, a number of parameters such as the number of cells tested, the culture medium, the antigen concentration and format, the background reactivity, and the incubation times can affect the final results. Many of these parameters have been identified by international harmonization efforts [12-14]. The analysis (i.e., the counting of spots with the ELISpot reader) should also be thoroughly performed [15]. Hence, each laboratory should establish and optimize the assay for its own in-house conditions, define optimal quantification and linearity ranges, and implement measures for controlling performance between operators and over time. 


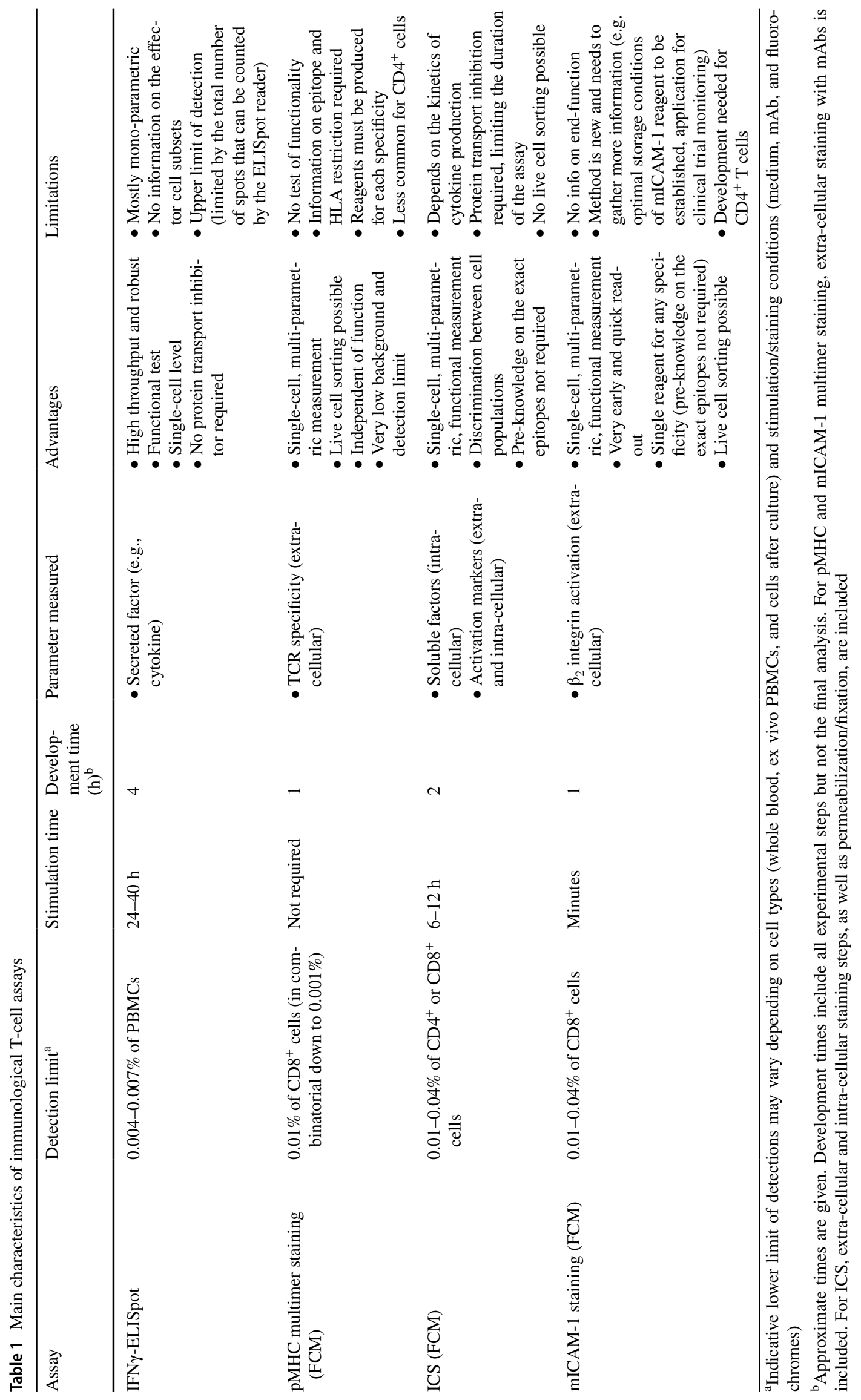




\section{FCM: single-cell, multi-parametric, and versatile}

Apart from the ELISpot, other popular methods used for conventional T-cell monitoring are based on flow cytometry (FCM). FCM is the prototype of a multi-parameter, singlecell assessment method which allows the simultaneous phenotypic and functional characterization of various cell subsets contained in a cell mixture, for example PBMCs.

Automated single-cell flow analysis was first mentioned in 1934 and further developed by Wallace Coulter in the 1950s. The first fluorescence-based commercial device, a "pulse cytophotometer", and cell sorters, became available in the late 1960s. FCM has considerably improved since then, with major developments in the technology itself, as well as in the reagents and fluorochromes that are available. FCM remains an indispensable state of the art technique in basic research and in clinical development. Simultaneous measurement of more than eight parameters is daily practice in many laboratories. Still, for rigorous and meaningful testing, and especially if many parameters are combined, it is absolutely essential to invest efforts in establishing and optimizing antibody panels and in controlling cytometer performance over time [16]. A number of specialized articles and books have already been published by leading experts in FCM [17-19] and specific tools are also available, such as tutorials on the websites of academic institutions or antibody manufacturers. Similarly to the ELISpot assay, harmonization initiatives have helped to increase performance and comparability of the results obtained at different centers [14, 20-22]. Attention should be given not only to the experiments themselves, but also to their analysis. Flow gating strategies are not standardized and contribute substantially to inter-laboratory variation $[23,24]$. As FCM complexity is steadily increasing, such efforts should be sustained in the future.

\section{Peptide-MHC multimer staining}

The introduction of pMHC fluorescent multimers more than 20 years ago was a groundbreaking innovation which has boosted many aspects of T-cell research, especially the characterization of low-frequency antigen-specific $\mathrm{T}$ cells [25]. pMHC multimers bind to antigen-specific T cells due to the interaction of pMHC complexes with TCRs. The affinity of one pMHC molecule for its cognate TCR is generally low and not sufficiently stable to stain antigen-specific cells. To bypass this problem, pMHC monomers (produced by in vitro refolding of biotinylated recombinant $\mathrm{MHC}$ chains in the presence of the peptide of interest) can be multimerized by taking advantage of the strong interaction between biotin and streptavidin (described in [26]). Various formats of pMHC multimers are available, from tetramers to more elaborate constructs containing ten or more pMHC monomers [25,
27]. Multimers are in principle very stable, but low affinity peptides might dissociate over time. Degradation can be prevented either by adding free peptide to the reagent, or by freezing multimers in the presence of glycerol, which will ensure stability of the reagents for at least 6 months [28]. pMHC class I tetramers can be produced in-house and are by far the most common multimers used to stain $\mathrm{CD} 8^{+} \mathrm{T}$ cells. pMHC class II tetramers are more difficult to produce and remain rarely used for assessment of antigen-specific $\mathrm{CD} 4^{+} \mathrm{T}$ cells.

The assay itself has a high specificity $(<0.002 \%$ in our hands for common virus-specific $\mathrm{CD} 8^{+} \mathrm{T}$ cells) and a detection limit down to approx. $0.01 \%$ of $\mathrm{CD}^{+} \mathrm{T}$ cells, allowing the examination of rare cell populations [9, 29]. Optimizations, including combinatorial staining (usage of the same tetramers labeled with two different fluorochromes), can greatly improve the detection limit of the assay, increasing the chance to detect (tumor) antigen-specific $\mathrm{T}$ cells in ex vivo blood or PBMCs [30].

In combination with $\mathrm{mAb}$ that characterize $\mathrm{T}$-cell subsets, pMHC multimers are perfect reagents to identify antigenspecific cells of interest in a cell sample, without functional assessment. This can be an advantage, as all cells specific for a certain antigen will be detected, irrespective of their function. The problem with such "structural information" is that the cells detected may be anergic or dysfunctional and as such will probably not be efficient effectors. A wellknown example in the virology field is the accumulation of Cytomegalovirus (CMV)-specific $\mathrm{CD} 8^{+} \mathrm{T}$ cells in the elderly; these cells can be detected by pMHC staining but are essentially dysfunctional [31].

\section{The intra-cellular cytokine assay}

The ICS assay presents the advantage of delivering comprehensive information on the functional profile of the T-cell subsets of interest [32]. Upregulation of early functional markers can be detected, such as CD107a (degranulation, essentially for $\left.\mathrm{CD} 8^{+} \mathrm{CTLs}\right)$ or CD154 (CD40L, preferentially expressed on activated $\mathrm{CD} 4^{+} \mathrm{T}$ cells and detected intra-cellularly, unless a CD40 mAb is added) [33, 34]. This can be combined with the detection of intra-cellular cytokines. T cells that produce several cytokines at the same time, the so-called polyfunctional $\mathrm{T}$ cells, have been associated with protection after vaccination and with favorable clinical outcome in various pathogen-related conditions [35]. A correlation with anti-tumor protection, however, has still to be determined. Nevertheless, polyfunctional T cells not only produce several cytokines which could reflect advanced effector function, but these cytokines, particularly IFN- $\gamma$, are also produced in enhanced amounts at the singlecell level [35]. 
ICS is mainly used when the exact epitopes and/or the MHC restriction are not identified (e.g., when using overlapping (long) peptides for T-cell screening), and for assessment of $\mathrm{CD}^{+}{ }^{+} \mathrm{T}$-cell responses $[36,37]$. It is an elaborate assay, and each step should be carried out carefully in order to deliver optimal results. Cell treatment (thawing, antigen stimulation, and staining), mAb combinations, and analysis, need to be optimized in each laboratory. For the identification of low T-cell responses in particular, it is important to keep the background cytokine/marker production in the unstimulated control condition as low as possible. This background varies between cytokines and is generally enhanced when cells have been cultured, but is optimally in the range of approx. $0.01-0.04 \%$ (within $\mathrm{CD} 4^{+} / \mathrm{CD}^{+}$subsets), hence greater than that of pMHC multimers. Standardized protocols are available $[38,39]$ and parameters important for performance have been identified in inter-laboratory testing exercises [21-23].

There are two intrinsic limitations to the ICS assay. First, the duration of the antigen stimulation is restricted. To enable intra-cellular staining of accumulated cytokines, cells are treated with protein transport inhibitors. Such inhibitors are toxic and should generally not be added for more than $12 \mathrm{~h}$ $[33,38]$. This time frame needs to be accommodated to the kinetics of production for the various cytokines that are to be detected [10]. To circumvent this problem, one possibility is to first add the stimulus, and several hours later the inhibitors [40]. Second, the detection of intra-cellular structures requires the permeabilization and fixation of the cells. As a consequence, the cells cannot be used for live cell sorting and/or recovered for further in vitro culture. Finally, it is important to note that the combination of pMHC multimer staining and ICS is not possible, since antigenic stimulation triggers the rapid downregulation of the TCR, precluding multimer binding on cytokine ${ }^{+} \mathrm{T}$ cells.

\section{The mICAM-1 assay: immediate structural changes indicate T-cell function}

The execution of $\mathrm{CD} 8^{+} \mathrm{T}$-cell effector responses requires strong adhesion to target cells (e.g., cancer cells), formation of an efficient immunological synapse and finally, killing of the target cells [41, 42]. Adhesion is mediated by activation of $\beta_{2}$-integrins such as LFA-1 (heterodimer CD11a/ CD18), which are expressed at high levels on circulating antigen-experienced $\mathrm{T}$ lymphocytes [43], but are maintained in an inactive state [44]. Following binding of the TCR to its specific antigen presented on target cell MHC molecules, integrin activation occurs within seconds by means of a process known as "inside-out" signaling. This leads both to an affinity increase and to clustering of membrane-bound integrins $[45,46]$. Because the integrins do not need to be synthesized de novo, this signaled adhesion response is very fast and allows binding to their ligands ICAM-1 (i.e., CD54), formation of the immunological synapse, a polarized release of secretory vesicles including cytokines, chemokines and lytic factors, and thereby effective cell killing.

As discussed above, different methods are being used for assessing antigen-specific $T$ cells and the choice of one or several of these for routine application in a particular laboratory will depend on the information sought for, and often on the experience and the technical environment of the team. If the exact antigens are known, in particular for $\mathrm{CD} 8^{+} \mathrm{T}$ cells, read-out with pMHC multimers will allow a very robust assessment of low-frequency $\mathrm{T}$ cells, irrespective of their functionality. On the one hand, it means that functionally defective cells could be detected [31], but on the other hand, if effector cells do produce TNF, but not IFN- $\gamma$, they could be missed by IFN- $\gamma$ ELISpot, but prove detectable with appropriate pMHC multimers, as we recently observed [37]. We have now introduced a new assay which identifies antigen-specific $\mathrm{CD} 8^{+} \mathrm{T}$ cells by specifically detecting activated integrin molecules with fluorescent ICAM-1 [47]. The principle of this assay is depicted in Fig. 1, and relies on the interaction of activated LFA-1 with its ligand ICAM-1, which occurs rapidly during T-cell activation. The affinity of activated LFA- 1 for monomeric ICAM-1 $\left(K_{\mathrm{d}}=0.5 \mu \mathrm{M}\right)$ [48] is within the affinity range of the TCR for a monomeric pMHC $\left(K_{\mathrm{d}}=0.1-400 \mu \mathrm{M}\right)$ [49], and weaker than the nanomolar affinity of an antibody for its antigen. In addition, the interaction LFA-1/ICAM-1 lasts a few seconds $\left(t_{1 / 2}=\ln 2 / k_{\text {diss }}=\sim 7 \mathrm{~s}\right)$ [48], and is in the same range as that of TCR/pMHC ( 0.5 to approx. $30 \mathrm{~s})[49,50]$. Therefore, to stably detect the activated integrins, pre-assembled multimeric ICAM-1 (mICAM-1) with higher avidity had to be used. These multimers can be produced by pre-incubating recombinant ICAM-1-Fc molecules with fluorescent polyclonal anti-Fc antibodies, and used in FCM [51]. After carefully optimizing the multimer production and the staining conditions, we showed that the method is suitable for the detection of antigen-specific $\mathrm{CD} 8^{+} \mathrm{T}$ cells against a range of antigens (e.g., CMV, HIV, EBV, Flu, and YFV) and for various cell preparations (whole blood, fresh and frozen/thawed PBMCs, and in vitro expanded T cells) [47]. We also used the assay to detect tumor antigen-specific $\mathrm{CD} 8^{+} \mathrm{T}$ cells from prostate carcinoma patients who had received a multi-peptide vaccine; hence, mICAM-1 binding can also be used to measure tumor antigen-specific T cells [47]. Compared with previous methods for assessing functional antigen-specific $\mathrm{CD} 8^{+} \mathrm{T}$ cells, our assay detects changes in the avidity of surface integrins rather than de novo production of (intra-cellular) proteins. This produces clear benefits, including the short activation time (typically only a few minutes when using short peptides, i.e., exact epitopes, as stimuli, and slightly longer-approx. 30 min-when using overlapping 15 mers), and the simplicity 


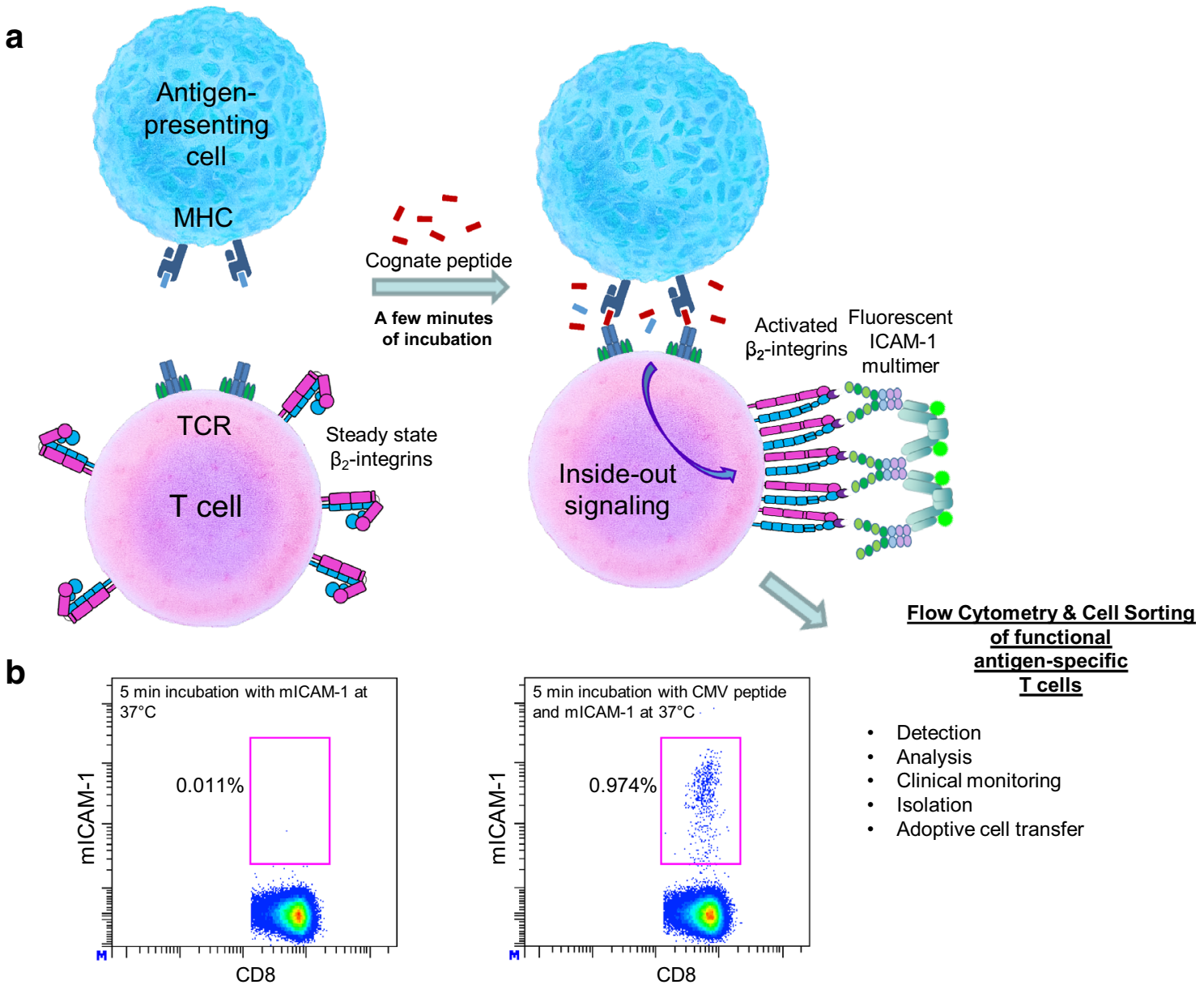

Fig. 1 Assessment of adhesion as a T-cell monitoring tool. a Principle of the assay: following $\mathrm{T}$-cell receptor-mediated stimulation, integrin activation occurs within seconds through a process known as "inside-out" signaling which leads to an affinity increase and a clustering of membrane-bound integrins. Fluorescent intercellular adhesion molecule 1 multimers (mICAM-1) bind specifically to activate $\beta_{2}$ integrins and can be used in flow cytometry for fast monitoring and isolation of antigen-specific T cells. b Example of mICAM-1 $(1.56 \mu \mathrm{g} / \mathrm{ml})$ staining after $5 \mathrm{~min}$ activation of the blood of an HLA$\mathrm{A} 2^{+} \mathrm{CMV}$ seropositive healthy donor in the absence (left) or presence (right) of the synthetic peptide NLVPMVATV (pp65-derived, HLA-A2 binding immunodominant epitope of CMV) at $4 \mu \mathrm{g} /$ ml. Cells were stained with mICAM-1 PE, CD8 BV605, and CD3 BV510; dot plots are gated on $\mathrm{CD}^{+} \mathrm{CD}^{+}$lymphocytes of the staining procedure. The assessment of integrin activation can be combined with other staining reagents to derive detailed information about antigen-specific $\mathrm{T}$ cells, such as pMHC multimers, as well as surface and intra-cellular markers. The short stimulation time would not allow a significant change in the expression of these factors, which is the case for the long incubation time required to detect cytokines. Hence, the assay is likely to nearly reflect the in vivo situation. Significantly, we showed that (1) while the two assays correlate very tightly, only a fraction of pMHC-tetramer positive cells also bind mICAM multimers after antigen-specific stimulation, (2) mICAM-1 staining highly correlated with cytokine production (IFN- $\gamma$ and TNF) and CD107a upregulation, (3) mICAM-1 binding correlates very well with perforin and granzyme $\mathrm{B}$ expression, and 4$) \mathrm{CD}^{+} \mathrm{T}$ cells that bind
mICAM-1 after antigen stimulation can be found in both the effector and memory subsets. Based on these observations, we concluded that activated integrins represent a very early marker that identifies functional (very likely cytotoxic) $\mathrm{CD}^{+}$ T cells. mICAM-1 staining could be used not only for detection of antigen-specific cells, but also to address the effects of certain substances, or (immune) cell subsets, on T-cell function. For example, we recently used the assay for assessing the impact of $\mathrm{G} \alpha_{\mathrm{s}}$-coupled receptor agonists and sleep on T-cell function [52]. In addition, one attractive asset of the mICAM assay is that it preserves cell viability and cytokine production, allowing fast and easy isolation of functional cells [47].

The main characteristics of the mICAM assay are compared to those of established methods in Table 1. The 
background staining, i.e., the staining in the unstimulated control condition, is approx. $0.01-0.04 \%$ in our hands, hence comparable to that of the ICS assay. Some individuals show an increased background staining, particularly when using frozen/thawed cells, but the overall signal-to-noise ratio can be optimized. The mICAM-1 reagent is stable for months when kept at $4{ }^{\circ} \mathrm{C}$; however, the background staining slightly increases when stored for more than a month under this condition. This can be prevented by freezing the multimers at $-80{ }^{\circ} \mathrm{C}$ (all unpublished data). For $\mathrm{CD} 8^{+} \mathrm{T}$ cells, the combination of pMHC multimers and mICAM-1 staining is perfect for a fast, high-sensitivity assessment of total and functional numbers of antigen-specific $\mathrm{T}$ cells of interest.

\section{Conclusion and perspectives}

There is more than ever a major interest in the assessment of immune cells, and in particular $\mathrm{T}$ cells, in cancer immunotherapies, and in pathogen-driven diseases. A number of assays are available to monitor antigen-specific T cells. Since none of these assays alone is able to capture the entire range of T-cell properties and functions, the best option is probably to combine two complementary tests, especially when monitoring clinical studies. Assessment of conformation changes in adhesion molecules on $\mathrm{T}$ cells can be specifically detected with ICAM-1 multimers and exploited for rapid identification of functional $\mathrm{T}$ cells. The method could be useful for monitoring T-cell immunity in health and disease, after vaccination, or during various immunotherapies. Because it preserves cell viability and functionality, it might also evolve as a precious tool to isolate highly functional $\mathrm{CD}^{+} \mathrm{T}$ lymphocytes for further gene expression or protein analysis, as well as for adoptive transfer strategies. Presumably, mICAM- $1^{+}$antigen-specific $\mathrm{CD} 8^{+} \mathrm{T}$ cells with their strong functional capacity, ensure protective immunity and thus can be used as correlates of protection. This, however, still needs to be evaluated. In the next step, we are planning to validate the assay and to implement it as an exploratory monitoring tool in the context of an upcoming multi-peptide-based vaccination trial for glioma patients.

Acknowledgements We thank all colleagues involved in developing the mICAM-1 method as well as L. Yakes and M. Hallschmid for proofreading.

Author contributions Stoyan Dimitrov and Cécile Gouttefangeas developed the mICAM multimer method. Cécile Gouttefangeas, Juliane Schuhmacher, and Stoyan Dimitrov wrote and revised the manuscript.

Funding This work was partially supported by the Deutsche Forschungsgemeinschaft (SFB685 to Cécile Gouttefangeas). Stoyan Dimitrov was supported by grants from the German Federal Ministry of Education and Research (BMBF) to the German Center for Diabetes Research (DZD e.V.; 01GI0925)

\section{Compliance with ethical standards}

Conflict of interest The authors declare that they have no conflict of interest.

\section{References}

1. van der Burg SH (2018) Correlates of immune and clinical activity of novel cancer vaccines. Semin Immunol 39:119-136. https://doi. org/10.1016/j.smim.2018.04.001

2. Riaz N, Havel JJ, Makarov V, Desrichard A, Urba WJ, Sims JS, Hodi FS, Martin-Algarra S, Mandal R, Sharfman WH, Bhatia S, Hwu WJ, Gajewski TF, Slingluff CL, Chowell D, Kendall SM, Chang H, Shah R, Kuo F, Morris LGT, Sidhom JW, Schneck JP, Horak CE, Weinhold N, Chan TA (2017) Tumor and microenvironment evolution during immunotherapy with nivolumab. Cell 171(4):934-949 e916. https://doi.org/10.1016/j.cell.2017.09.028

3. Han A, Glanville J, Hansmann L, Davis MM (2014) Linking T-cell receptor sequence to functional phenotype at the singlecell level. Nat Biotechnol 32(7):684-692. https://doi.org/10.1038/ nbt. 2938

4. Danilova L, Anagnostou V, Caushi JX, Sidhom JW, Guo H, Chan HY, Suri P, Tam A, Zhang J, Asmar ME, Marrone KA, Naidoo J, Brahmer JR, Forde PM, Baras AS, Cope L, Velculescu VE, Pardoll DM, Housseau F, Smith KN (2018) The mutation-associated neoantigen functional expansion of specific T cells (MANAFEST) assay: a sensitive platform for monitoring antitumor immunity. Cancer Immunol Res 6(8):888-899. https://doi.org/10.1158/23266066.CIR-18-0129

5. Woodsworth DJ, Castellarin M, Holt RA (2013) Sequence analysis of T-cell repertoires in health and disease. Genome Med 5(10):98. https://doi.org/10.1186/gm502

6. Czerkinsky CC, Nilsson LA, Nygren H, Ouchterlony O, Tarkowski A (1983) A solid-phase enzyme-linked immunospot (ELISPOT) assay for enumeration of specific antibody-secreting cells. J Immunol Methods 65(1-2):109-121

7. Janetzki S (2016) Elispot for Rookies (and Experts Too). Techniques in Life Science and Biomedicine for the Non-Expert. Springer International Publishing

8. Moodie Z, Price L, Gouttefangeas C, Mander A, Janetzki S, Lower M, Welters MJ, Ottensmeier C, van der Burg SH, Britten CM (2010) Response definition criteria for ELISPOT assays revisited. Cancer Immunol Immunother 59(10):1489-1501. https://doi. org/10.1007/s00262-010-0875-4

9. Comin-Anduix B, Gualberto A, Glaspy JA, Seja E, Ontiveros M, Reardon DL, Renteria R, Englahner B, Economou JS, GomezNavarro J, Ribas A (2006) Definition of an immunologic response using the major histocompatibility complex tetramer and enzymelinked immunospot assays. Clin Cancer Res 12(1):107-116. https ://doi.org/10.1158/1078-0432.CCR-05-0136

10. Duechting A, Przybyla A, Kuerten S, Lehmann PV (2017) Delayed activation kinetics of Th2- and Th17 cells compared to Th1 cells. Cells. https://doi.org/10.3390/cells6030029

11. Maecker HT, Hassler J, Payne JK, Summers A, Comatas K, Ghanayem M, Morse MA, Clay TM, Lyerly HK, Bhatia S, Ghanekar SA, Maino VC, Delarosa C, Disis ML (2008) Precision and linearity targets for validation of an IFNgamma ELISPOT, cytokine flow cytometry, and tetramer assay using CMV peptides. BMC Immunol 9:9. https://doi.org/10.1186/1471-2172-9-9

12. Cox JH, Ferrari G, Kalams SA, Lopaczynski W, Oden N, D'Souza MP (2005) Results of an ELISPOT proficiency panel conducted in 11 laboratories participating in international human 
immunodeficiency virus type 1 vaccine trials. AIDS Res Hum Retroviruses 21(1):68-81. https://doi.org/10.1089/aid.2005.21.68

13. Janetzki S, Panageas KS, Ben-Porat L, Boyer J, Britten CM, Clay TM, Kalos M, Maecker HT, Romero P, Yuan J, Kast WM, Hoos A (2008) Results and harmonization guidelines from two large-scale international Elispot proficiency panels conducted by the Cancer Vaccine Consortium (CVC/SVI). Cancer Immunol Immunother 57(3):303-315. https://doi.org/10.1007/s00262-007-0380-6

14. Britten CM, Gouttefangeas C, Welters MJ, Pawelec G, Koch S, Ottensmeier C, Mander A, Walter S, Paschen A, Muller-Berghaus J, Haas I, Mackensen A, Kollgaard T, Thor Straten P, Schmitt M, Giannopoulos K, Maier R, Veelken H, Bertinetti C, Konur A, Huber C, Stevanovic S, Wolfel T, van der Burg SH (2008) The CIMT-monitoring panel: a two-step approach to harmonize the enumeration of antigen-specific CD8+ T lymphocytes by structural and functional assays. Cancer Immunol Immunother 57(3):289-302. https://doi.org/10.1007/s00262-007-0378-0

15. Janetzki S, Price L, Schroeder H, Britten CM, Welters MJ, Hoos A (2015) Guidelines for the automated evaluation of Elispot assays. Nat Protoc 10(7):1098-1115. https://doi.org/10.1038/nprot .2015 .068

16. Gouttefangeas C (2015) Flow cytometry in cancer immunotherapy: applications, quality assurance, and future. In: Rezaei N (ed) Cancer immunology. Springer, Berlin

17. Perfetto SP, Ambrozak D, Nguyen R, Chattopadhyay PK, Roederer M (2012) Quality assurance for polychromatic flow cytometry using a suite of calibration beads. Nat Protoc 7(12):2067-2079. https://doi.org/10.1038/nprot.2012.126

18. Herzenberg LA, Tung J, Moore WA, Parks DR (2006) Interpreting flow cytometry data: a guide for the perplexed. Nat Immunol 7(7):681-685. https://doi.org/10.1038/ni0706-681

19. Finak G, Langweiler M, Jaimes M, Malek M, Taghiyar J, Korin Y, Raddassi K, Devine L, Obermoser G, Pekalski ML, Pontikos N, Diaz A, Heck S, Villanova F, Terrazzini N, Kern F, Qian Y, Stanton R, Wang K, Brandes A, Ramey J, Aghaeepour N, Mosmann T, Scheuermann RH, Reed E, Palucka K, Pascual V, Blomberg BB, Nestle F, Nussenblatt RB, Brinkman RR, Gottardo R, Maecker H, McCoy JP (2016) Standardizing flow cytometry immunophenotyping analysis from the human immuno phenotyping consortium. Sci Rep 6:20686. https://doi.org/10.1038/srep20686

20. Attig S, Price L, Janetzki S, Kalos M, Pride M, McNeil L, Clay T, Yuan J, Odunsi K, Hoos A, Romero P, Britten CM (2011) A critical assessment for the value of markers to gate-out undesired events in HLA-peptide multimer staining protocols. J Transl Med 9:108. https://doi.org/10.1186/1479-5876-9-108

21. Jaimes MC, Maecker HT, Yan M, Maino VC, Hanley MB, Greer A, Darden JM, D'Souza MP (2011) Quality assurance of intracellular cytokine staining assays: analysis of multiple rounds of proficiency testing. J Immunol Methods 363(2):143-157. https:// doi.org/10.1016/j.jim.2010.08.004

22. Welters MJ, Gouttefangeas C, Ramwadhdoebe TH, Letsch A, Ottensmeier CH, Britten CM, van der Burg SH (2012) Harmonization of the intracellular cytokine staining assay. Cancer Immunol Immunother 61(7):967-978. https://doi.org/10.1007/s0026 2-012-1282-9

23. McNeil LK, Price L, Britten CM, Jaimes M, Maecker H, Odunsi K, Matsuzaki J, Staats JS, Thorpe J, Yuan J, Janetzki S (2013) A harmonized approach to intracellular cytokine staining gating: results from an international multiconsortia proficiency panel conducted by the Cancer Immunotherapy Consortium (CIC/CRI). Cytometry A 83(8):728-738. https://doi.org/10.1002/cyto.a.22319

24. Gouttefangeas C, Chan C, Attig S, Kollgaard TT, Rammensee HG, Stevanovic S, Wernet D, Thor Straten P, Welters MJ, Ottensmeier C, van der Burg SH, Britten CM (2015) Data analysis as a source of variability of the HLA-peptide multimer assay: from manual gating to automated recognition of cell clusters. Cancer
Immunol Immunother 64(5):585-598. https://doi.org/10.1007/ s00262-014-1649-1

25. Altman JD, Moss PA, Goulder PJ, Barouch DH, McHeyzerWilliams MG, Bell JI, McMichael AJ, Davis MM (1996) Phenotypic analysis of antigen-specific $\mathrm{T}$ lymphocytes. Science 274(5284):94-96

26. Davis MM, Altman JD, Newell EW (2011) Interrogating the repertoire: broadening the scope of peptide-MHC multimer analysis. Nat Rev Immunol 11(8):551-558. https://doi.org/10.1038/nri3020

27. Batard P, Peterson DA, Devevre E, Guillaume P, Cerottini JC, Rimoldi D, Speiser DE, Winther L, Romero P (2006) Dextramers: new generation of fluorescent MHC class I/peptide multimers for visualization of antigen-specific CD8+ T cells. J Immunol Methods 310(1-2):136-148. https://doi.org/10.1016/j.jim.2006.01.006

28. Hadrup SR, Maurer D, Laske K, Frosig TM, Andersen SR, Britten CM, van der Burg SH, Walter S, Gouttefangeas C (2015) Cryopreservation of MHC multimers: recommendations for quality assurance in detection of antigen specific T cells. Cytometry A 87(1):37-48. https://doi.org/10.1002/cyto.a.22575

29. Chandran PA, Laske K, Cazaly A, Rusch E, Schmid-Horch B, Rammensee HG, Ottensmeier CH, Gouttefangeas C (2018) Validation of immunomonitoring methods for application in clinical studies: the HLA-peptide multimer staining assay. Cytometry B Clin Cytom 94(2):342-353. https://doi.org/10.1002/cyto.b.21397

30. Andersen RS, Kvistborg P, Frosig TM, Pedersen NW, Lyngaa R, Bakker AH, Shu CJ, Straten P, Schumacher TN, Hadrup SR (2012) Parallel detection of antigen-specific T cell responses by combinatorial encoding of MHC multimers. Nat Protoc 7(5):891902. https://doi.org/10.1038/nprot.2012.037

31. Ouyang Q, Wagner WM, Wikby A, Walter S, Aubert G, Dodi AI, Travers P, Pawelec G (2003) Large numbers of dysfunctional CD8+ T lymphocytes bearing receptors for a single dominant CMV epitope in the very old. J Clin Immunol 23(4):247-257

32. Jung T, Schauer U, Heusser C, Neumann C, Rieger C (1993) Detection of intracellular cytokines by flow cytometry. J Immunol Methods 159(1-2):197-207

33. Betts MR, Brenchley JM, Price DA, De Rosa SC, Douek DC, Roederer M, Koup RA (2003) Sensitive and viable identification of antigen-specific CD8+ T cells by a flow cytometric assay for degranulation. J Immunol Methods 281(1-2):65-78

34. Frentsch M, Arbach O, Kirchhoff D, Moewes B, Worm M, Rothe M, Scheffold A, Thiel A (2005) Direct access to CD4+ T cells specific for defined antigens according to CD154 expression. Nat Med 11(10):1118-1124. https://doi.org/10.1038/nm1292

35. Seder RA, Darrah PA, Roederer M (2008) T-cell quality in memory and protection: implications for vaccine design. Nat Rev Immunol 8(4):247-258. https://doi.org/10.1038/nri2274

36. Singh SK, Meyering M, Ramwadhdoebe TH, Stynenbosch LF, Redeker A, Kuppen PJ, Melief CJ, Welters MJ, van der Burg SH (2012) The simultaneous ex vivo detection of low-frequency antigen-specific CD4+ and CD8+ T-cell responses using overlapping peptide pools. Cancer Immunol Immunother 61(11):1953-1963. https://doi.org/10.1007/s00262-012-1251-3

37. Loffler MW, Chandran PA, Laske K, Schroeder C, Bonzheim I, Walzer M, Hilke FJ, Trautwein N, Kowalewski DJ, Schuster H, Gunder M, Carcamo Yanez VA, Mohr C, Sturm M, Nguyen HP, Riess O, Bauer P, Nahnsen S, Nadalin S, Zieker D, Glatzle J, Thiel K, Schneiderhan-Marra N, Clasen S, Bosmuller H, Fend F, Kohlbacher O, Gouttefangeas C, Stevanovic S, Konigsrainer A, Rammensee HG (2016) Personalized peptide vaccine-induced immune response associated with long-term survival of a metastatic cholangiocarcinoma patient. J Hepatol 65(4):849-855. https ://doi.org/10.1016/j.jhep.2016.06.027

38. Lamoreaux L, Roederer M, Koup R (2006) Intracellular cytokine optimization and standard operating procedure. Nat Protoc 1(3):1507-1516. https://doi.org/10.1038/nprot.2006.268 
39. Horton H, Thomas EP, Stucky JA, Frank I, Moodie Z, Huang Y, Chiu YL, McElrath MJ, De Rosa SC (2007) Optimization and validation of an 8-color intracellular cytokine staining (ICS) assay to quantify antigen-specific $\mathrm{T}$ cells induced by vaccination. J Immunol Methods 323(1):39-54. https://doi.org/10.1016/j. jim.2007.03.002

40. Kaveh DA, Whelan AO, Hogarth PJ (2012) The duration of antigen-stimulation significantly alters the diversity of multifunctional CD4 T cells measured by intracellular cytokine staining. PLoS One 7(6):e38926. https://doi.org/10.1371/journal.pone.0038926

41. Dustin ML (2014) The immunological synapse. Cancer. Immunol Res 2(11):1023-1033. https://doi.org/10.1158/2326-6066. CIR-14-0161

42. Scholer A, Hugues S, Boissonnas A, Fetler L, Amigorena S (2008) Intercellular adhesion molecule-1-dependent stable interactions between $\mathrm{T}$ cells and dendritic cells determine CD8+ T cell memory. Immunity 28(2):258-270. https://doi.org/10.1016/j.immun i. 2007.12 .016

43. Dimitrov S, Benedict C, Heutling D, Westermann J, Born J, Lange $\mathrm{T}$ (2009) Cortisol and epinephrine control opposing circadian rhythms in T cell subsets. Blood 113(21):5134-5143. https://doi. org/10.1182/blood-2008-11-190769

44. Evans R, Patzak I, Svensson L, De Filippo K, Jones K, McDowall A, Hogg N (2009) Integrins in immunity. J Cell Sci 122(Pt 2):215-225. https://doi.org/10.1242/jcs.019117

45. Dustin ML, Long EO (2010) Cytotoxic immunological synapses. Immunol Rev 235(1):24-34. https://doi.org/10.111 1/j.0105-2896.2010.00904.x

46. Long EO (2011) ICAM-1: getting a grip on leukocyte adhesion. J Immunol 186(9):5021-5023. https://doi.org/10.4049/jimmu nol.1100646

47. Dimitrov S, Gouttefangeas C, Besedovsky L, Jensen ATR, Chandran PA, Rusch E, Businger R, Schindler M, Lange T, Born J,
Rammensee HG (2018) Activated integrins identify functional antigen-specific CD8(+) T cells within minutes after antigen stimulation. Proc Natl Acad Sci USA 115(24):E5536-E5545. https:// doi.org/10.1073/pnas.1720714115

48. Tominaga Y, Kita Y, Satoh A, Asai S, Kato K, Ishikawa K, Horiuchi T, Takashi T (1998) Affinity and kinetic analysis of the molecular interaction of ICAM-1 and leukocyte function-associated antigen-1. J Immunol 161(8):4016-4022

49. Aleksic M, Liddy N, Molloy PE, Pumphrey N, Vuidepot A, Chang KM, Jakobsen BK (2012) Different affinity windows for virus and cancer-specific T-cell receptors: implications for therapeutic strategies. Eur J Immunol 42(12):3174-3179. https://doi.org/10.1002/ eji.201242606

50. Stone JD, Chervin AS, Kranz DM (2009) T-cell receptor binding affinities and kinetics: impact on T-cell activity and specificity. Immunology 126(2):165-176. https://doi.org/10.111 1/j.1365-2567.2008.03015.x

51. Konstandin MH, Wabnitz GH, Aksoy H, Kirchgessner H, Dengler TJ, Samstag Y (2007) A sensitive assay for the quantification of integrin-mediated adhesiveness of human stem cells and leukocyte subpopulations in whole blood. J Immunol Methods 327(1-2):30-39. https://doi.org/10.1016/j.jim.2007.07.005

52. Dimitrov S, Lange T, Gouttefangeas C, Jensen ATR, Szczepanski M, Lehnnolz J, Soekadar S, Rammensee HG, Born J, Besedovsky L (2019) Galphas-coupled receptor signaling and sleep regulate integrin activation of human antigen-specific T cells. J Exp Med. https://doi.org/10.1084/jem.20181169

Publisher's Note Springer Nature remains neutral with regard to jurisdictional claims in published maps and institutional affiliations. 